\title{
THE IMPORTANCE OF MOUNTAIN GEOMORPHOSITES FOR ENVIRONMENTAL EDUCATION: EXAMPLES FROM THE ITALIAN DOLOMITES AND THE SWISS ALPS
}

Emmanuel Reynard, Paola Coratza

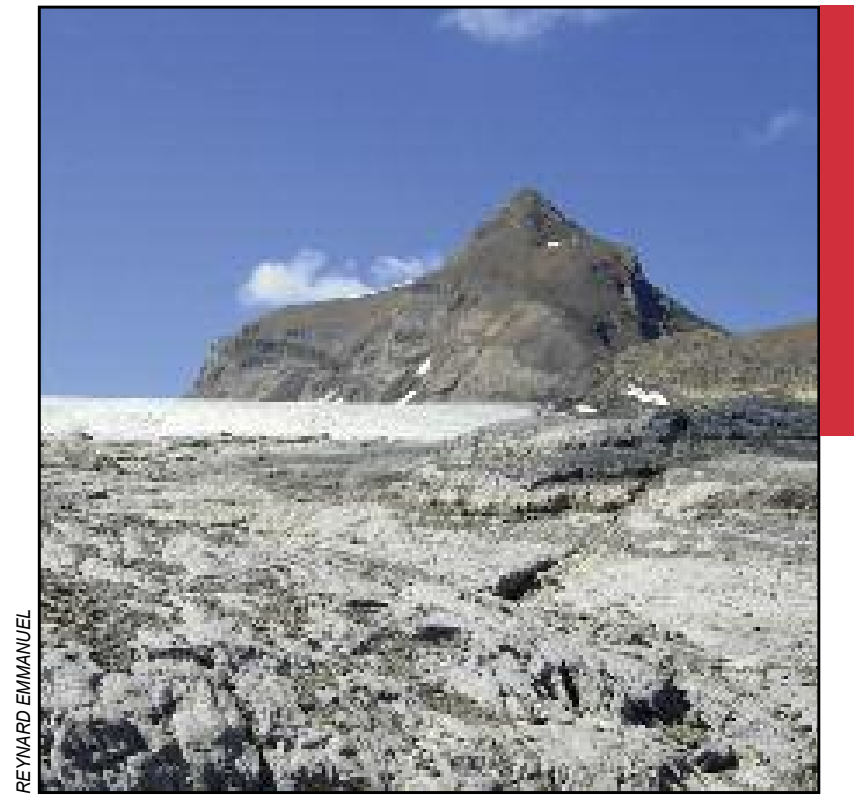

Tsanfleuron glacio-karstic area, Switzerland. 


\section{The importance of mountain geomorphosites for environmental education}

DOI: http://dx.doi.org/10.3986/AGS.1684

UDC: $911.2: 551.4(234.3)$

COBISS: 1.01

ABSTRACT: Because of their specific physical characteristics (altitude, slope, orientation, climate), mountain environments have an important natural diversity. In particular, their geodiversity is generally much larger than in the lowlands, and because mountain geosites are often very aesthetic, mountain areas present a great potential for geoheritage, geoconservation and geotourism studies. This paper reviews six reasons why this potential is high and concludes that mountain areas are particularly interesting to develop educational programs on three current environmental issues: climate change; natural hazards; and human impacts on particularly sensitive geomorphological environments. Then, the paper reviews the principal research in the field of geoheritage currently carried out on these three topics and presents two case studies in the Italian Dolomites and the Swiss Alps.

KEY WORDS: geomorphological heritage, geomorphosites, geotourism, mountain geomorphology, Alps

The article was submitted for publication on July $18^{\text {th }}, 2014$.

\section{ADDRESSES:}

Emmanuel Reynard, Ph.D.

University of Lausanne

Institute of Geography and Sustainability

Mouline - Géopolis, 1015 Lausanne, Switzerland

E-mail: emmanuel.reynard@unil.ch

\section{Paola Coratza, Ph.D.}

University of Modena and Reggio Emilia

Department of chemical and Earth sciences

Largo S. Eufemia, 19, 41121 Modena, Italy

E-mail: paola.coratza@unimore.it 


\section{Introduction: mountains as open-air laboratories for environment education}

Heritage is a complex concept, both contested and culturally constructed, depending on personal and collective backgrounds and experiences. The perception and the definition of what constitutes heritage, its significance and the way it should be preserved and used may vary deeply from person to person or at least from groups of people or communities to others (Aplin 2002).

Frequently heritage is artificially divided into natural and cultural components (e.g. World heritage), even if this kind of distinction is often meaningless and almost always blurred. The artificiality of such division is clearly witnessed by geomorphosites (Panizza 2001; Reynard et al. 2009) and more in general by the concept of geological or geomorphological landscape (Reynard 2005). We observe and admire many landscapes, which have been altered by human activities - the so-called »cultural landscapes « - and which represent the relationships between physical and anthropogenic components that interacted, are conditioned and still condition the landscape, in space and in time.

Referring to what is stated in the Declaration of the rights of the international memory of the Earth, "our history and the history of the Earth cannot be separated. Its origins are our origins, its history is our history and its future will be our future " and "as an ancient tree retains the record of its life and growth, the Earth retains memories of the past inscribed both in its depths and on its surface, in the rocks and in the landscape, a record which can be read and translated « (Actes ... 1994, 273). Since the geological landscapes have recorded the whole history of the Earth - the geohistory (see Pralong 2006) -, landforms are the visible symbols and the perceptible evidence of this continuous evolution. For this reason the landscape should be perceived and offered as a value, as a heritage.

Recent decades have witnessed an exponential growth of scientific research in mountain environments (e.g. Beniston 2003; Gruber et al. 2012) and in this context the value of geoheritage in mountain areas has been re-discovered in various parts of the Alps (Reynard et al. 2011) and other mountain ranges.

Several characteristics make the mountain environments areas with a great potential for geoheritage, geoconservation and geotourism studies (Giusti et al. 2013):

- Mountain areas are internally diverse, variable and dynamic, due to their elevation, relief, and exposure. They are, therefore, recognized as natural areas with a very high geodiversity, especially the Alpine collisional orogens (Benito-Calvo et al. 2009) in contrast with Tertiary foreland sedimentary basins. This high landform diversity (Thomas 2012, Zwolişski and Stachoviak 2012), often over very short distances, provides open-air laboratories where processes and landscape evolution can be studied and transmitted to a non-specialized public.

- Mountain areas often combine active landforms and processes (active geomorphosites) and inherited landforms (passive geomorphosites) (Thomas 2012; Pelfini and Bollati 2014), as well as evolving passive geomorphosites (Pelfini and Bollati 2014), that is inherited landforms that are reactivated by current active processes. In particular, many mountain areas show clear evidence of late-Pleistocene glaciations and, more in general, evidence of processes that have occurred in different morphoclimatic systems. The active geomorphosites have a high educational value because they allow us to: understand and visualize geomorphological processes in action; envisage the landscape evolution; highlight their relationship with present societies and their future development. Passive geomorphosites, which bring us to the past, have a particular heritage value as records and symbols of Earth's history and evolution.

- Many mountain environments, especially the glacial ones, are very sensitive areas, particularly vulnerable to disturbance and prone to change, where climate change impacts are very acute (e.g. Ravanel (2011) on rockfalls, Stoffel and Huggel (2012) on mass movements, and Haeberli and Beniston (1998) on the cryosphere). Changes are visible at very short time scales and may generate active processes, very evident to observe, such as landslides, thermokarstic landforms or rockfalls due to permafrost melting.

- Mountain areas are also sensitive to natural hazards related to snow processes (avalanches), fluvial and torrential processes (Wohl 2000), as well as processes related to the melting of the cryosphere (Haeberli 1992).

- Mountain landscapes have often a central aesthetic character, which was at the basis of the tourism development in the Alps in the $18^{\text {th }}$ century (Nicolson 1959) and which confers a great potential for the development of geotourism (Cayla 2010). In fact, one could start from aesthetic and landscape perceptions in order to stimulate the knowledge of geological-geomorphological components of the landscape in the general public. 
- Finally, mountain ranges, in particular the Alps, have been at the core of important discoveries in the Earth sciences, such as the concept of nappes by M. A. Bertrand (Dal Piaz 2001), the pluri-glacialism (Penck and Bruckner 1909) or the origin of erratic blocks (e.g. Reynard 2004).

These characteristics make mountain areas particularly suitable for educational and tourist purposes. This paper focuses on the importance of mountain geomorphosites for environmental education. It is based on the idea that, because of the characteristics listed above, mountain environments are sites particularly interesting for communicating and educating people (e.g. tourists, scholars) on three main current environmental issues:

- climate change and its impacts on societies, and related adaptation measures;

- natural hazards related to climate forcing and human pressure on the environment;

- human impacts on particularly sensitive geomorphological environments.

After having briefly reviewed the current research carried out on these three topics, we propose two case studies, in the Italian Dolomites and in the Swiss Alps, before a discussion on the interest of mountain geomorphosites for environmental education.

\section{Current research on mountain geomorphosites}

We have already reviewed the main improvements concerning research on geomorphosites during the last twelve years (Reynard and Coratza 2013). Here we focus on the three thematic issues presented above.

Several scholars have dealt with climate change impacts on specific types of geomorphosites. Diolaiuti and Smiraglia (2010) discussed the issue of glacial geomorphosites that are melting in a context of climate warming; they consider glaciers as a vanishing resource. The glacier recession provokes the formation of new landforms and landscape features, in particular an increase of debris-covered glaciers and thermokarst features (kettles, supraglacial lakes) or the generation of debris flows initiating in recently deglaciated glacier forefields. In this sense, glacier forefields are particularly well-suited areas for observing climate change impacts on the cryosphere and related landforms (Barboux et al. 2014). In particular, the Forni glacier, in the Lombardy Alps, where a geotourist trail was equipped in the early 2000s, is becoming an »open air environmental museum of deglaciation " (Diolaiuti and Smiraglia 2010, 148). Similar experiences (in-depth geomorphological survey associated with geotourism development) are carried out on the Miage Glacier, in the Italian Mont-Blanc massif (e.g. Bollati et al. 2013). Garavaglia et al. (2010) demonstrated the interest of dendrochronological methods for studying glacier geomorphosites. Ravanel et al. (2014) also showed recently the great potential of using specific techniques (laser scanning) for measuring landform evolution in high-mountain active and sensitive geomorphosites. Bosson and Reynard (2010) combined several cartographic approaches (geomorphological mapping, geosystemic mapping, reconstruction of glacial stages) for communicating the dynamics of mountain environments to the managers of the Contamines-Montjoie natural reserve managers, in the Mont-Blanc massif. Nevertheless, research on the sensitivity of mountain geomorphosites to climate change still remains undeveloped. In particular, periglacial contexts are poorly addressed in a geotourist and geoconservation point of view, even if their sensitivity to climate change is actively studied. That is also the case of particularly active processes related to climate warming and extreme events, in particular debris flows. Educational programs in these kinds of sites (e.g. torrential systems) should be developed for specific publics such as tourists or scholars, as it was proposed by Garavaglia and Pelfini (2011).

The relationships between natural hazards and geomorphological heritage has also been poorly addressed until now. Alcántara Ayala (2009) proposed a general discussion on these relationships, and Italian scholars developed a methodology to assess risk and geomorphological heritage along (geo)tourist trails (Piccazzo et al. 2007, Coratza et al. 2008, Pelfini et al. 2009). Several case studies focused on the importance of active geosites for explaining the dynamics of geomorphological processes in mountain environments (e.g. Pelfini et al. 2009; Garavaglia and Pelfini 2011; Pelfini and Bollati 2014). Research on passive geomorphosites and past catastrophes are less developed. Recently, Coratza and De Waele (2012) discussed the importance of sites that were prone to natural hazards in the past for environmental education. They stressed that »important landmarks produced by past hazards, especially if they have an aesthetical appeal, may be important geomorphosites ideal to promote geological education " (Coratza and De Waele 2012, 195). Nevertheless, they noted that only in very few cases (e.g. Vajont in Northern Italy) past 
catastrophes are included in large educational programs aimed at demonstrating the importance of the relationships between geology and society. Especially in tourist areas, authorities may be reluctant to communicate on past disasters as this could scare tourists. All these studies demonstrate that both active and inactive geomorphosites may be of interest for educating people (scholars, tourists, hikers) to the dynamics of mountain geomorphological processes, to the relationships between geology and society (in particular to the impacts of human infrastructures on the triggering of some catastrophes), and to the evolution of mountain risks through time. In this sense, several sites in the Alps could become hotspots for the education to natural hazards, even if at the moment this kind of educational and geotourist product is poorly developed.

Finally, one should stress the fact that human development has great impacts on the particularly sensitive mountain ecosystems. Some of these impacts are linked to the geological and geomorphological contexts. This is, in particular, the case of karstic environments, where pollution issues are related to the specificities of the karstic geomorphological features (Hobléa 2009). French and Slovenian scholars have been particularly active on these issues. Gauchon et al. (2006) and Hobléa et al. (2008) addressed questions concerning the protection of underground karst by using the concept of heritage resource. They stressed the fact that the protection of the endokarstic heritage needs to address territorial planning issues, involving people and communities living in areas quite distant to the areas to protect. In order to involve local populations in the management of their geomorphological heritage, Hobléa et al. (2011) developed the concept of »hybrid research", that is a research protocol including scholars and local population in the experimentation. In particular, they tested this approach in tracing experiments to better understand underground water circulations. In this context, Erhartič (2010) addressed the issue of karstic features protection through a cartographic approach. In another paper (Komac et al. 2012), the geomorphologists of the Anton Melik Geographical Institute stressed the importance of managing geomorphosites in a dynamic way: the objective should be more to conserve (i.e. to allow the sites to evolve in the future) than to preserve them (i.e. to fix the sites in their present state).

This brief literature review shows how specific mountain geomorphosites could be equipped for developing education programs dealing with current environmental issues such as impacts of climate change on environmental processes, natural hazards management and mitigation, and environmental impacts of human activities (e.g. water pollution). Nevertheless, even if there is a great potential for this kind of educational activities, the Alps, and mountain ranges in general, lack at the moment of articulated programs for environmental education based on specific geomorphosites. In the next section, we develop the case of two sites - one at the regional scale (Dolomites), and one at the local scale (Tsanfleuron geomorphosite), where this kind of program could be developed.

\section{Case studies}

\subsection{The Sassolungo Group, Gardena Valley, Dolomites (Italy)}

The Dolomites - universally known for their scenic beauty and scientific interest and proclaimed in 2009 as a UNESCO »Word Heritage « site - make up a unique natural environment on our planet. The long and complex geological and geomorphological history of this region has created typical and spectacular landforms with huge vertical cliffs, whitish, silver or pink rock pinnacles and towers rising from green slopes made up of darker and brittle rocks, with woods, pastures and scattered hamlets. Due to their high geomorphodiversity (Panizza 2009), the Dolomites can be considered as a high-altitude field laboratory for research, development of geomorphological theories and understanding, as well as for the development of effective educational and dissemination strategies and activities (Bruschi et al. 2009).

The area, considered in the present study, is located in the southeastern portion of Gardena Valley, in particular in the upper part of the valley, mainly occupied by the Sassolungo Group (more than $3000 \mathrm{~m}$ ). The area has a strong hiking-tourism vocation thanks to its spectacular high-mountain landscape and a dense network of hiking tracks. The well-developed network of hiking paths and slopes for many different climbing skills offer a lot of possibilities for high-mountain excursions. Permanent dwelling-places are absent with the exceptions of a few tourist structures nearby opened during certain periods of the year.

From a geological viewpoint, the Sassolungo Group is formed by limestone and dolomite formations referable to the Sciiliar Group (Upper Anisian-Lower Carnian). These correspond to dolomites and dolomitic 

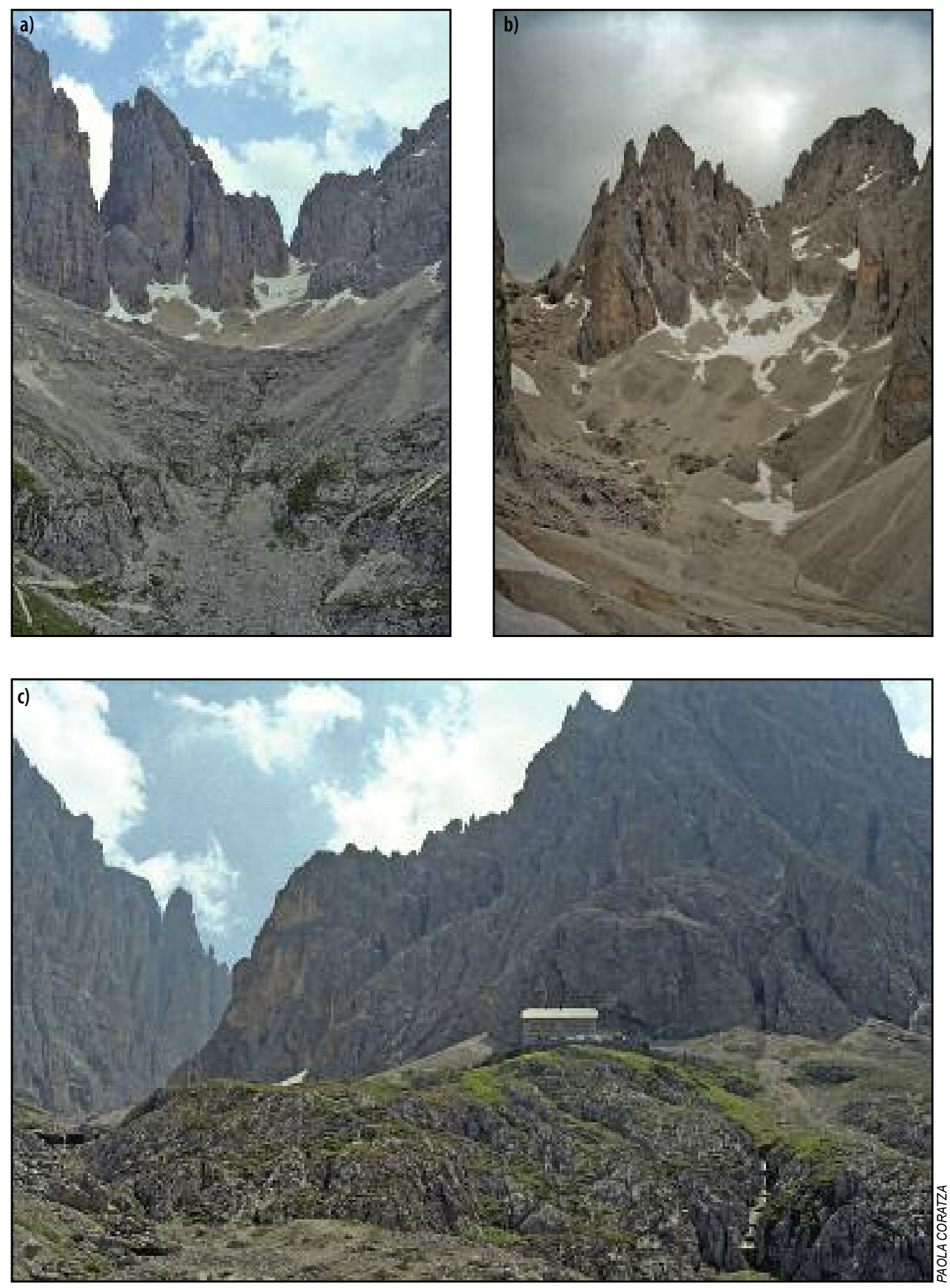

Figure 1: Examples of glacial landforms present in the Gardena Valley: worthy of note are the well preserved glacial cirques located in the northern slope of Sassolungo Group, at the Sasso Levante (a) and near Punta Dantersas at about $2740 \mathrm{~m}$ A.S.L. (b), as well as roches moutonnées located in the eastern slope of Sassopiatto (c). 

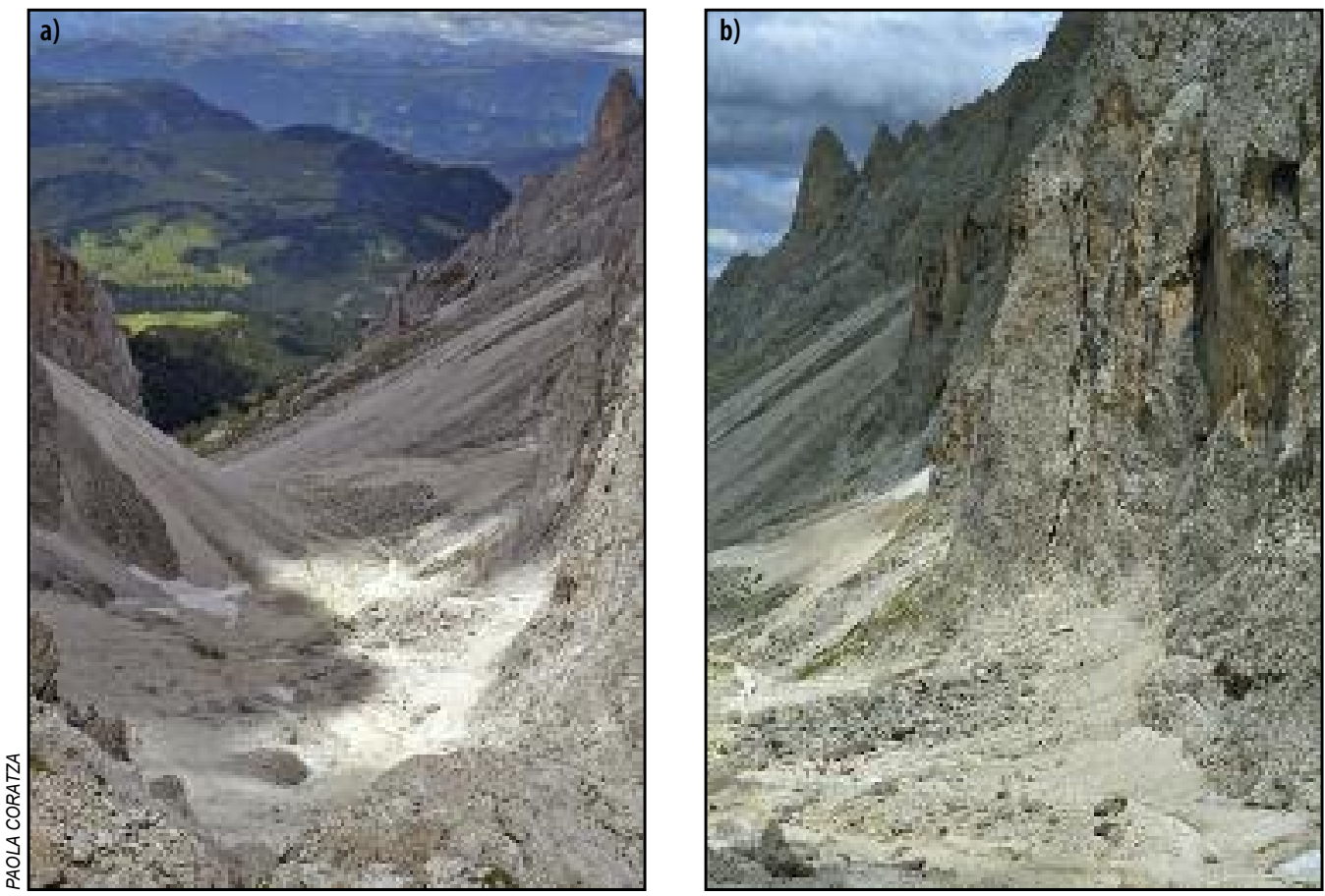

Figure 2: Examples of landforms and processes active in the current morphoclimatic conditions: partially active talus cones (a) and rock-fall accumulation in the narrow Sassolungo valley (b). Both landforms and the related processes are responsible for hazards, which might threaten the safety of visitors and tourists.

limestones, very light pearl pink or whitish, in some rare cases reddish or greyish, in color, usually not stratified. The group is characterized by subvertical cliffs (up to 700 meters high) which make up the source of the thick scree deposits that are accumulated at the foot of the walls and join the cliffs to the more gentle slopes made up of darker and softer terrain, mainly consisting of Wengen Formation (Upper Ladinian).

This area, as with all the Dolomites, represents landscape mosaics, which express the summation of landscape histories and processes (Thomas 2001), offering an almost complete educational open-air laboratory due to the variety and complexity of phenomena and processes taking place during present climate conditions and during recent geological periods. These mountains, due to the aggregation of relict, recent and active landforms constitute an outstanding geoheritage, suitable for educational and tourist purposes. Landforms typical of past morphoclimatic conditions (passive geomorphosites) share the stage with forms and processes active in the current morphoclimatic conditions (active geomorphosites); their spatial and geometrical relationships may be sufficient to trace a relative time-line of the geomorphological history of the area. That history represents an important piece of information: as cities are visited by tourists thanks to their historical heritage (monuments etc.), the landscape also has its own historical heritage (geosites and geomorphosites) to be discovered, understood and therefore appreciated (Coratza et al. 2008). As in all the Dolomites, structural and geological characteristics represent the main factors controlling the landscape of the area (Coratza et al. 2005). Depending on the lithology, different litho-structural forms have developed: dolomitic outcrops have been highly fractured under tectonic pressure, developing large and deep channels that cut through the massifs and a dense network of several fracture systems that amplify cryogenic processes. Several glacial landforms are present in the valley, showing the presence and the activity of ancient glaciers (Figure 1). Worthy of note are the well preserved glacial cirques located in the northern slope of Sassolungo Group, at the Sasso Levante and near Punta Dantersas at about $2740 \mathrm{~m}$, as well as roches moutonnées located in the eastern slope of Sassopiatto.

The gravity-induced slope landforms and processes are the most recurrent geomorphological features active since the end of the Lateglacial within the area (Figure 2). The water of snow melting and heavy rain- 
fall, occurring mainly between June and September, together with the wide availability of frost shattering material, cause concentrated runoff ditches, debris flows and active talus and scree slopes, partially covering traces of palaeforms related to periglacial and glacial processes. Moreover, several spectacular falls and topples detaching from over $2000 \mathrm{~m}$ high peaks of Sassolungo Group are clearly visible and witness the dynamicity of processes in the area. Among the most evident rock-fall accumulations and talus cones, worthy of notice are those located on slopes at the base of the dolomite massif of Sassolungo Group, crossed by a well-frequented hiking track.

The landforms and processes active in the current morphoclimatic conditions may be responsible for hazards, which might threaten the safety of visitors and tourists (Brandolini et al. 2006; Pelfini et al. 2009; Bollati et al. 2013; Pelfini and Bollati 2014). In particular, fast-occurring processes might directly involve tourists in proximity to the sites of interest or along access roads and footpaths. By examining the chronicles of accidents that occurred in Alpine areas during the past few years, it results that debris flows and falls are the processes, which should be taken into account more than any other. This is true essentially for three reasons: the first is the very close link between these natural phenomena and extreme meteoric events, which now take place with extremely irregular recurrence and higher frequency than in the past; the second reason is linked to the considerable velocities that a mass of debris can attain, thus also threatening people moving fast in the surroundings; the third reason concerns the difficulty of identifying the source areas of these disarray phenomena.

Therefore, this area constitutes an outstanding open-air laboratory suitable for developing new ways and strategies to educate hikers to the dynamicity of mountains environments and to natural geomorphological risks, favoring an easy understanding of the landscape and of its hazards and a responsible and safe fruition of high-mountain tourist areas.

\subsection{The Tsanfleuron glacio-karst, Western Swiss Alps}

The Tsanfleuron glacio-karstic geomorphosite is one of the largest karstic areas of the Swiss Alps. It is characterized by a complex combination of karstic and glacial processes, unique at the country scale, which

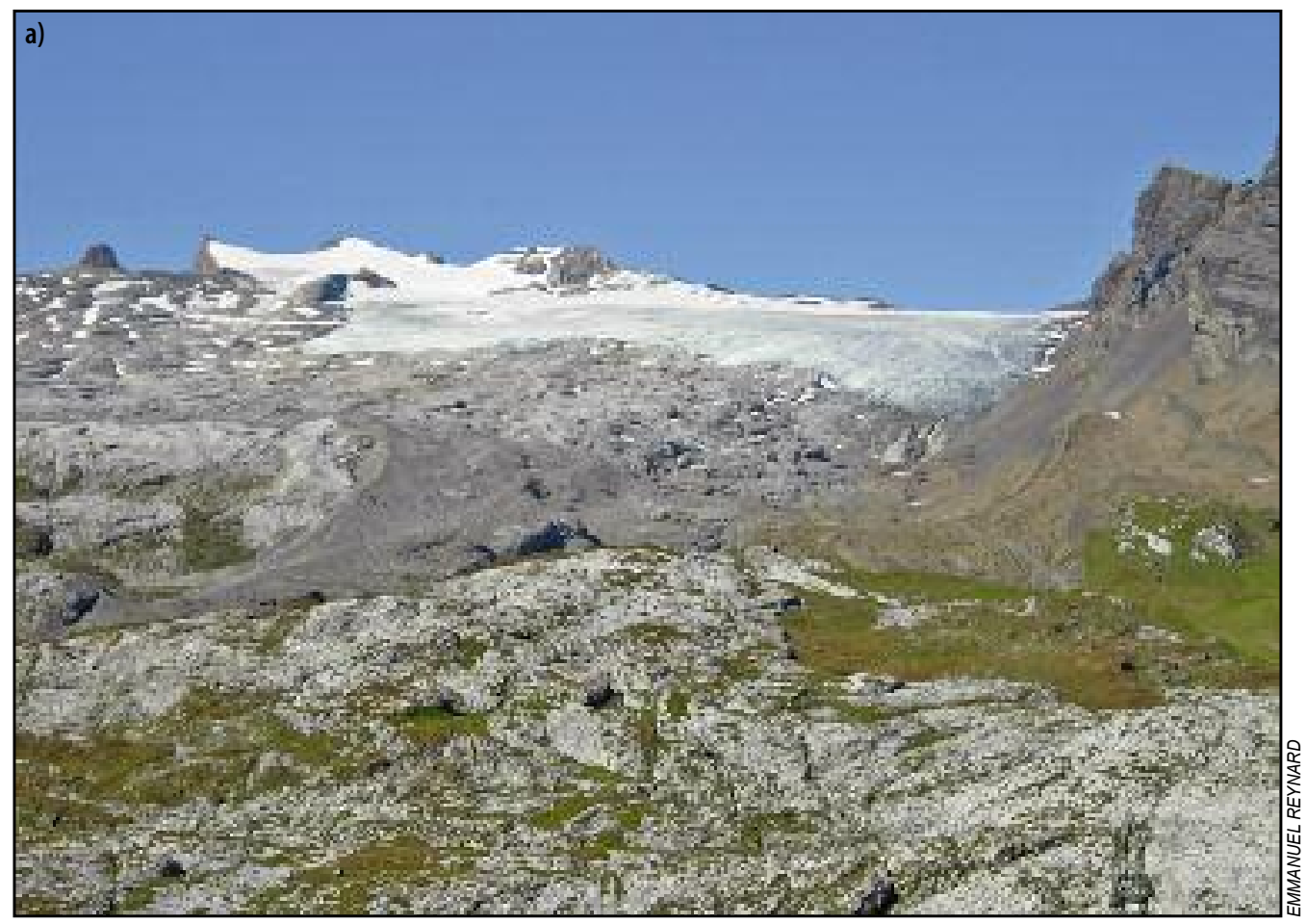



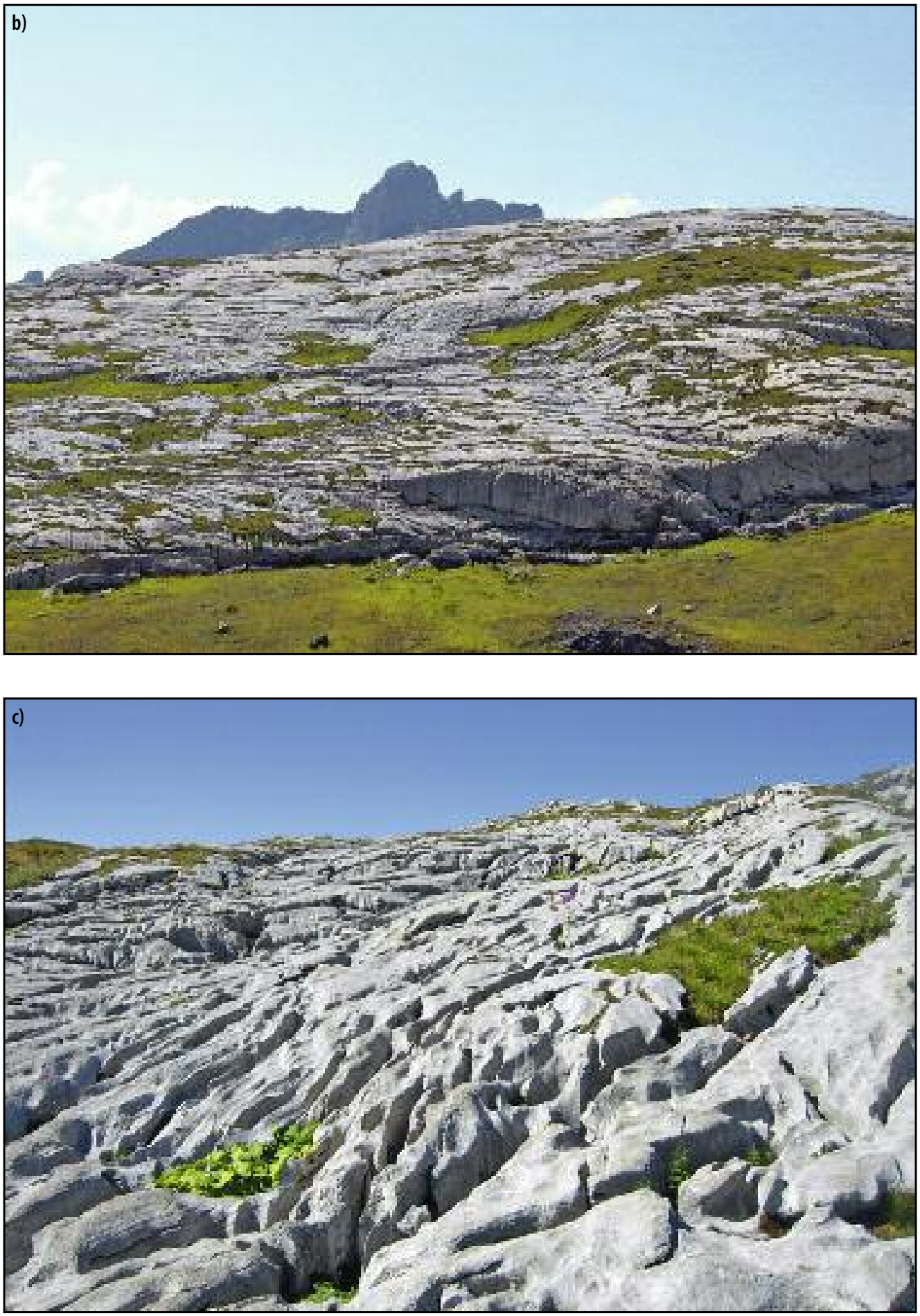

Figure 3: (a) A view of the glacio-karst of Tsanfleuron. (b) The part of the karren field deglaciated since the beginning of the Holocene. (c) A detail of karren fields. 
makes it a rare and unique geosite in the Swiss Alps (Reynard 2008). These specificities have attracted Swiss and foreign researchers for the last 40 years, which makes the site one of the most studied and documented karstic sites in the Western Swiss Alps. This is one of the reasons why in 2006, the French Association of Karstology visited the area during its annual field trip (Hobléa et al. 2008). The karst is inscribed in the list of Swiss geosites for the unique combination of karstic and glacial landforms.

The Tsanfleuron karren field belongs to the Helvetic nappes and consists of Jurassic to Palaeogene sedimentary rocks (Gremaud et al. 2009). The nappe forms a vast anticlinorium, with Tertiary limestones outcropping in the downstream part and Cretaceous Urgonian limestones outcropping in the upper part. The latter is characterized by the presence of a glacier that is retreating very quickly, and allows a large set of glaciokarstic landforms (Nye channels, glaciokarstic depressions, carbonate precipitation microforms, etc.) to be visible. The combination of limestone outcrops and a network of pro- and subglacial streams creates complex underground water circulations (Gremaud et al. 2009; Gremaud and Goldscheider 2009) and impacts on the protection of springs captured for drinking water supply (Savoy et al. 2008).

The diversity of karstic and glacial landforms (Figure 3), the fast retreat of the Tsanfleuron glacier (Reynard 2006; Martin 2013), and the complexity of water circulations have induced the University of Lausanne to select this site as a hotspot for mountain geomorphology research, but also for the development of an educational program (Reynard 2008) on the mountain geomorphology and its sensitivity to climate change and to human impacts on the karstic environment (in particular water circulations). An educational brochure was produced, as well as a geotourist map (Martin and Reynard 2009) and an educational product - called "Rocks and Water « - was specifically dedicated to school children of the middle schools in the region. An interactive application - showing, in particular, the fast retreat of the glacier and also some glacial processes such as glacial erosion - was also created.

All these geotourist and educational products aim at developing a better understanding of current geomorphological processes in a high-mountain changing environment. A survey among the users (Martin 2013) shows that even if they are well illustrated with good-quality figures and maps, the message of such products remains still a little bit too difficult for users without specific knowledge in geosciences. This kind of realization should, therefore, be developed taking better into account the knowledge of the potential public (Martin 2013).

\section{Conclusion}

Mountain geomorphological features are often very impressive and aesthetic, and geomorphological processes are active and very visible in the landscapes. For all these reasons mountain geomorphosites seem to be particularly interesting sites for developing educational activities on environmental issues such as fast changing environments due to climate warming, natural hazards or human impacts on sensitive environmental sites. Nevertheless, at the moment, few sites have clearly been used for developing these kinds of activity. This is one of the objectives of the Working group on geomorphosites of the International Association of Geomorphologists (IAG) for the period 2013-2017.

ACKNOWLEDGEMENTS: This paper is dedicated to our colleague Bojan Erhartič, who disappeared too early in a plane crash in 2013 when he was returning home after fieldwork in the Slovenian mountains. Bojan took part for many years in the activities of the Working group on geomorphosites of the International Association of Geomorphologists (IAG) that we have had the honor of chairing since 2001 (Reynard and Coratza 2013). Bojan Erhartič was particularly active and took part, among other events, in the workshop on mapping issues organized in Lausanne in 2008 (Erhartič 2010), in the conference organized by our colleague Christian Giusti in Paris in 2009 (Erhartič et al. 2012, Komac et al. 2012), and more recently in the session on geomorphosites during the International Geomorphology Conference in Paris, in August 2013, a few weeks before he passed away. Bojan has played a central role in the development of geomorphosite studies in Slovenia (see for example his papers on geomorphosite assessment (Erhartič 2010) and on geodiversity and geomorphosite studies in Slovenia (Erhartič and Zorn 2012). We hope that his colleagues will continue his legacy and develop further research on the geomorphological heritage of Slovenia. The English proofreading by Meredith Blake is much appreciated. 


\section{References}

Actes du premier Symposium international sur la protection du patrimoine géologique 1994. Paris.

Alcántara Ayala, I. 2009: Geomorphosite management in areas sensitive to natural hazards. Geomorphosites. München.

Aplin, G. J. 2002: Heritage identification, conservation, and management. Victoria.

Barboux, C., Delaloye, R. Lambiel, C. 2014: Inventorying slope movements in an Alpine environment using DInSAR. Earth surface processes and landforms 39-15. DOI: http://dx.doi.org/10.1002/esp.3603

Beniston, M. 2003: Climatic change in mountain regions: A review of possible impacts. Climatic Change 59 1-2. DOI: http://dx.doi.org/10.1023/A:1024458411589

Benito-Calvo, A., Pérez-González, A., Magri, O., Meza, P. 2009: Assessing regional geodiversity: the Iberian Peninsula. Earth surface processes and landforms 34-10. DOI: http://dx.doi.org/10.1002/esp.1840

Bollati, I., Smiraglia, C., Pelfini, M. 2013: Assessment and selection of geomorphosites and trails in the Miage Glacier area (Western Italian Alps). Environmental Management 51-4. DOI: http://dx.doi.org/ 10.1007/s00267-012-9995-2

Brandolini, P., Faccini, F., Piccazzo, M. 2006: Geomorphological hazard and tourist vulnerability along Portofino Park trails (Italy). Natural hazards and Earth system sciences 6. DOI: http://dx.doi.org/10.5194/ nhess-6-563-2006

Bruschi, V. M., Coratza, P., Corsini, A., Marchetti, M., Panizza, M., Piacentini, D., Soldati, M. 2009: The role of geomorphology in land management. Field-trip guide. Modena.

Cayla, N. 2010: Les processus de construction du géotourisme alpin. Téoros 29-2. URL: http://teoros.revues.org/874

Coratza, P., De Waele, J. 2012: Geomorphosites and natural hazards: Teaching the importance of geomorphology in society. Geoheritage 4-3. DOI: http://dx.doi.org/10.1007/s12371-012-0058-0

Coratza, P., Ghinoi, A., Piacentini, D., Valdati, J. 2008: Management of geomorphosites in high tourist vocation area: an example of Geo-Hiking maps in the Alpe di Fanes (Natural Park of Fanes-Senes-Braies, Italian Dolomites). GeoJournal of Tourism and Geosites 2-2.

Coratza, P., Marchetti, M., Soldati, M. 2005: Geomorfologia e instabilità dei versanti del Gruppo del Sassolungo (Dolomiti occidentali). Geografia Fisica e Dinamicca Quaternaria 7.

Dal Piaz, G. V. 2001: History of tectonic interpretations of the Alps. Journal of geodynamics 32, 1-2. DOI: http://dx.doi.org/10.1016/S0264-3707(01)00019-9

Diolaiuti, G., Smiraglia, C. 2010: Changing glaciers in a changing climate: how vanishing geomorphosites have been driving deep changes in mountain landscapes and environments. Géomorphologie: relief, processus, environnement 2. DOI: http://dx.doi.org/10.4000/geomorphologie.7882

Erhartič, B. 2010: Geomorphosite assessment. Acta geographica Slovenica 50-2. DOI: http://dx.doi.org/ 10.3986/AGS50206

Erhartič, B., Komac, B., Zorn, M. 2012: Geomorphosites in Slovenia. Geomorphosites 2009: raising the profile of geomorphological heritage through iconography, inventory and promotion. Paris.

Erhartič, B., Zorn, M. 2012: Geodiversity and geomorphosite research in Slovenia. Geografski vestnik 84-1.

Garavaglia, V., Pelfini, M. 2011: Glacial geomorphosites and related landforms: A proposal for a dendrogeomorphological approach and educational trails. Geoheritage 3-1. DOI: http://dx.doi.org/10.1007/ s12371-010-0027-4

Garavaglia, V., Pelfini, M., Bollati, I. 2010: The influence of climate change on glacier geomorphosites: the case of two Italian glaciers (Miage Glacier, Forni Glacier) investigated through dendrochronology. Géomorphologie: relief, processus, environnement 2. DOI: http://dx.doi.org/10.4000/geomorphologie.7895

Gauchon, C., Ployon, E., Delannoy, J.-J., Hacquard, S., Hobléa, F., Jaillet, S., Perrette, Y. 2006: The concepts of heritage and heritage resource applied to karsts: protecting the Choranche caves (Vercors, France). Acta carsologica 35-2/3. DOI: http://dx.doi.org/10.3986/ac.v35i2-3.226

Giusti, C., Reynard, E., Bollati, I., Cayla, N., Coratza, P., Hobléa, F., Ilies, D., Martin, S., Megerle, H., Pelfini, M., Regolini, G., Sellier, D., Zorn, M., 2013. A new network on mountain geomorphosites. Geophysical research abstracts 15. EGU2013-6706.

Gremaud, V., Goldscheider, N. 2009: Geometry and drainage of a retreating glacier overlying and recharging a karst aquifer, Tsanfleuron-Sanetsch, Swiss Alps. Acta carsologica 39-2. DOI: http://dx.doi.org/10.3986/ ac.v39i 2.100 
Gremaud, V., Goldscheider, N., Savoy, L., Favre, G., Masson, H. 2009: Geological structure, recharge processes and underground drainage of a glacierised karst aquifer system, Tsanfleuron-Sanetsch, Swiss Alps. Hydrogeology journal 17-8. DOI: http://dx.doi.org/10.1007/s10040-009-0485-4

Gruber, S., Egli, M., Gärtner-Roer, I., Hoelzle, M. 2012: Preface: The mountain cryosphere - A holistic view on processes and their interactions. Geografiska Annaler A, Physical geography 94-2. DOI: http://dx.doi.org/ 10.1111/j.1468-0459.2012.00468.x

Haeberli, W. 1992: Construction, environmental problems and natural hazards in periglacial mountain belts. Permafrost and periglacial processes 3-2. DOI: http://dx.doi.org/10.1002/ppp.3430030208

Haeberli, W., Beniston, M. 1998: Climate change and its impacts on glaciers and permafrost in the Alps. Ambio 27-4.

Hobléa, F. 2009: Karstic geomorphosites: managing subterranean natural-cultural heritage sites. Geomorphosites. München.

Hobléa, F., Cayla, N., Renau, P. 2011: The concept of »hybrid research « applied to the geoheritage of the Bauges Massif (French Alps): When the promotion of the geoheritage helps geosciences and vice versa. GeoJournal of tourism and geosites 4-2.

Hobléa, F., Delannoy, J.-J., Gauchon, C., Hacquard, S., Jaillet, S., Ployon, E. 2008: Entre karstologie fondamentale et appliquée: létude de classement du site de Choranche/les Coulmes (Vercors, France). Karst de montagne: géomorphologie, patrimoine et ressources. Sion.

Hobléa, F., Reynard, E., Delannoy, J.-J. 2008: Karsts de montagne. Géomorphologie, patrimoine et ressources. Cahiers de géographie 7.

Komac, B., Zorn, M., Erhartič†, B. 2012: Loss of natural heritage from the geomorphological perspective. Do geomorphic processes shape or destroy the natural heritage? Geomorphosites 2009: raising the profile of geomorphological heritage through iconography, inventory and promotion. Paris.

Martin, S. 2013: Valoriser le géopatrimoine par la médiation indirecte et la visualisation des objets géomorphologiques. University of Lausanne, Faculty of Geosciences and Environment, Ph. D. Thesis. Lausanne.

Martin, S., Reynard, E. 2009: How can a complex geotourist map be made more effective? Popularisation of the Tsanfleuron heritage (Valais, Switzerland). $6^{\text {th }}$ European congress on regional geoscientific cartography and information systems 2 . Munich.

Nicolson, M. H. 1959: Mountain gloom and mountain glory: The development of the aesthetics of the infinite. Cornell.

Panizza M. 2001: Geomorphosites: concepts, methods and example of geomorphological survey. Chinese science bulletin 46 .

Panizza, M. 2009: The geomorphodiversity of the Dolomites (Italy): A key of geoheritage assessment. Geoheritage 1-1. DOI: http://dx.doi.org/10.1007/s12371-009-0003-Z

Pelfini, M., Bollati, I. 2014: Landforms and geomorphosites ongoing changes: Concepts and implications for geoheritage promotion. Quaestiones geographicae 33-1. DOI: http://dx.doi.org/10.2478/quageo-2014-0009

Pelfini, M., Brandolini, P., Carton, A. Piccazzo, M. 2009: Geotourist trails: a geomorphological risk-impact analysis. Geomorphosites. München.

Penck, A., Brückner, E. 1909: Die Alpen im Eiszeitalter. Leipzig.

Piccazzo, M., Brandolini, P., Pelfini, M. 2007: Clima e rischio geomorfologico in aree turistiche. Bologna.

Pralong, J.-P. 2006: Géotourisme et utilisation de sites naturels d'intérêt pour les sciences de la Terre. University of Lausanne, Faculty of Geosciences and Environment, Ph. D. Thesis. Lausanne.

Ravanel, L., 2011: Climate influence on rockfalls in high-Alpine steep rockwalls: The north side of the Aiguilles de Chamonix (Mont Blanc massif) since the end of the 'Little Ice Age'. The Holocene 21-2. DOI: http://dx.doi.org/10.1177/0959683610374887

Ravanel, L., Bodin, X., Deline, P. 2014: Using terrestrial laser scanning for the recognition and promotion of high-alpine geomorphosites. Geoheritage 6-2. DOI: http://dx.doi.org/10.1007/s12371-014-0104-1

Reynard, E. 2004: Protecting stones: conservation of erratic blocks in Switzerland. Dimension stone, New perspectives for a traditional building material. Leiden.

Reynard, E. 2006: Valorisation géotouristique du karst de Tsanfleuron. Gestion durable de l'environnement karstique. Sion.

Reynard, E. 2008: Le lapiaz de Tsanfleuron. Un paysage glacio-karstique à protéger et à valoriser. Karsts de montagne. Géomorphologie, patrimoine et ressources. Collection EDYTEM 7. 
Reynard, E., Coratza, P. 2013: Scientific research on geomorphosites. Geografia Fisica e Dinamica Quaternaria 36. Reynard, E., Coratza, P., Regolini-Bissig G. 2009: Geomorphosites. München.

Reynard, E., Hobléa, F., Cayla, N., Gauchon, C. 2011: Iconic sites for Alpine geology and geomorphology. Rediscovering heritage? Revue de Géographie Alpine 99-2. DOI: http://dx.doi.org/10.4000/rga.1435.

Savoy, L., Favre, G., Masotti, D. 2008: Hydrogéologie du karst de Tsanfleuron et essais multitraçages, années 2005 et 2006. Karsts de montagne. Géomorphologie, patrimoine et ressources. Collection EDYTEM 7.

Stoffel, M., Huggel, C. 2012: Effects of climate change on mass movements in mountain environments. Progress in physical geography 36-3. DOI: http://dx.doi.org/10.1177/0309133312441010

Thomas, M. 2001: Landscape sensitivity in time and space - an introduction. Catena 42, 2-4. DOI: http://dx.doi.org/10.1016/S0341-8162(00)00133-8

Thomas, M. 2012: A geomorphological approach to geodiversity - its applications to geoconservation and geotourism. Quaestiones geographicae 31-1. DOI: http://dx.doi.org/10.2478/v10117-012-0005-9

Wohl E. 2000: Mountain rivers. Washington.

Zwoliński, Z., Stachowiak, J. 2012: Geodiversity map of the Tatra National Park for geotourism. Quaestiones geographicae 31-1. DOI: http://dx.doi.org/10.2478/ v10117-012-0012-x 
